\title{
Potential of Optimal Preloading in Anti-CD20 Antibody Radioimmunotherapy: An Investigation Based on Pharmacokinetic Modeling
}

\author{
Peter Kletting, Christoph Meyer, Sven N. Reske, and Gerhard Glatting
}

\begin{abstract}
Recently, it has been suggested that the concept of preloading is limited by using a standard amount of unlabeled antibody. To identify the potential of optimal preloading, a pharmacokinetic model that describes the biodistribution of anti-CD20 antibody was developed. Simulations were conducted for different tumor burdens, spleen sizes, and tumor permeabilities. The optimal amount of unlabeled antibody was determined for each scenario. These simulations show that the currently administered standard amount is not optimal. A preload of $150 \mathrm{mg}$ or lower would result in equal or higher tumor uptake in all cases. For tumors with high permeability, the uptake of labeled antibody could be increased by a factor of 8.5 using the considerably reduced optimal preload. The most sensitive parameter for the choice of the optimal amount of unlabeled antibody is the tumor uptake index. The results indicate that a personalized approach for radioimmunotherapy (RIT) with anti-CD20 antibody is required to account for the interpatient variability. The optimal amount of unlabeled antibody, which has to be determined by using a pharmacokinetic model, could substantially improve tumor uptake and thus RIT with anti-CD20 antibody.
\end{abstract}

Key words: anti-CD20 antibody, pharmacokinetic modeling, preload, radioimmunotherapy

\section{Introduction}

$\mathbf{R}$ adioimmunotherapy (RIT) with anti-CD20 antibody is widely used in the treatment of non-Hodgkin lymphoma (NHL). ${ }^{1}$ The concept of preloading ${ }^{2-5}$ is applied to improve the biodistribution of the radiolabeled antibodies. ${ }^{1}$ Currently, a standard amount of unlabeled antibody, dependent on the body surface area, is administered. ${ }^{1}$ However, it has been suggested to reassess the cold preloading dose, ${ }^{6}$ as the unlabeled antibody represents a competitor of labeled antibody for free antigen sites in the tumor. ${ }^{7}$ Further, it has been proposed that for RIT with anti-CD20 antibody an optimal amount of antibody, leading to the most favorable biodistribution, does exist for each individual patient. ${ }^{7}$ As the unlabeled antibody has a treatment effect itself, larger amounts of unlabeled anti-CD20 antibody could be administered after the radioactivity dose as consolidation. ${ }^{8}$

In this study, the potential of optimal preloading with respect to a maximal absorbed dose in the tumor is investi- gated using a pharmacokinetic model. The model incorporates the distribution of antibody to antigen sites, the competitive binding of labeled and unlabeled antibody, ${ }^{9}$ and the degradation of bound and unbound antibody. ${ }^{5,10}$ Model simulations are conducted to estimate the antibody preload that leads to the most favorable biodistribution under varying conditions such as different tumor and spleen sizes or different uptake indexes of antibody in tumor, as variability for such parameters is known to be high. ${ }^{2,11}$ This quantitative biodistribution analysis is a pivotal step for personalizing the treatment toward a more effective RIT with anti-CD20 antibody.

\section{Materials and Methods}

Model

A pharmacokinetic model (Fig. 1 and Appendix 1) was developed to describe the biodistribution of ${ }^{111}$ In-labeled anti-CD20 antibody using the modeling software MATLAB

Klinik für Nuklearmedizin, Universität Ulm, Ulm, Germany. 
Simulink. ${ }^{12}$ The basic features ${ }^{5,9,10}$ and parameters ${ }^{2,13}$ are derived from the literature and described below. Equal biodistribution of ${ }^{111} \mathrm{In}$ - and ${ }^{90} \mathrm{Y}$-labeled anti-CD20 antibody is assumed.

For reasons of parsimony the numbers of compartments and parameters were reduced to a minimum. Thus, only two antigen sites-"readily accessible" and "tumor"-were implemented in the model and the uptake of antibody into the tumor $\left(k_{\mathrm{in}, \mathrm{tu}}\right)$ is simplified to the product of tumor mass Mass $_{\text {tu }}$ and tumor uptake index (TUI). ${ }^{14}$ The "tumor" compartment includes all B cells of the lymph nodes and tumor, which are not readily accessible. The highly accessible antigen sites of the blood, red marrow, spleen, and liver ${ }^{10}$ are merged into one compartment named "readily accessible antigen sites" ( $\left.\mathrm{Ag}_{\mathrm{ra}}\right)$. The number of $\mathrm{Ag}_{\text {ra }}$ was derived from the literature for normal adults. ${ }^{13}$ The increased number of such antigens due to NHL was taken into account by simulating different spleen sizes. Many antigen sites in the lymph nodes or lymphomas are less accessible, ${ }^{15,16}$ and thus the uptake of antibody in this tissue has been modeled in two steps: first, the transport of antibody through the capillary wall $\left(k_{\mathrm{in}, \mathrm{tu}}\right)$, and second, the binding to B cells. The antibody is also distributed to the interstitial spaces of normal tissue without antigens $\left(k_{\mathrm{in}, \mathrm{n}}\right.$ and $\left.k_{\text {out }, \mathrm{n}}\right)$.

The monovalent and bivalent association $\left(k_{\mathrm{on}, \mathrm{mono}}\right.$ and $\left.k_{\text {on,bi }}\right)$ and dissociation ( $k_{\text {off,mono }}$ and $\left.k_{\text {off,bi }}\right)$ of antibody to antigen, as well as degradation of bound $\left(\lambda_{\mathrm{db}}\right)$ and unbound antibody $\left(\lambda_{\mathrm{du}}\right)$ has been incorporated in the model. ${ }^{5,9}$ Competitive binding of labeled and unlabeled antibody ${ }^{5}$ was modeled by using two circulation systems (composed of the described features), which are connected by the assumed stationary total number of antigens $\mathrm{Ag}_{0, \mathrm{i}}$ and the radioactive decay $\lambda_{\text {phy }}{ }^{5}$ (Fig. 1, Supplemental Data).

\section{Model simulations}

The simulations focus on the variation of tumor size, tumor uptake rate, and size of the spleen. The preload is "infused" at a constant rate over 255 minutes. ${ }^{17}$ The labeled antibody is "injected" in the 256th minute, as a bolus. The biodistribution was simulated for 1 week. The optimal biodistribution is defined as the maximal ratio of the residence times of tumor and total body $\tau_{\text {tu }} / \tau_{\text {total }}$.

\section{Optimal preload depending on tumor burden}

In a normal adult the mass of B cells found in all lymph nodes adds up to $\sim 38 \mathrm{~g}$, assuming that $20 \%$ of the $1.9 \times 10^{11}$ lymphocytes in the lymph nodes are B cells. ${ }^{13}$ An average expression of CD20 antigens of 149,000 per cell ${ }^{18}$ leads to $0.25 \mathrm{nmol}$ of CD20 per $1 \mathrm{~g}$ of B cells. Knox et al. ${ }^{2}$ reported a variation of tumor size from $<25$ to $>500 \mathrm{~g}$. To account for such variability, a range of tumor antigen number $\left(\mathrm{Ag}_{\mathrm{tu}}\right)$ of $3.6-328 \mathrm{nmol}$ (increment $36 \mathrm{nmol}$ ) was investigated. The TUI and $\mathrm{Ag}_{\mathrm{ra}}$ were set constant to the base values of $4 \mathrm{~mL} / 100 \mathrm{~g} /$ hour and $12 \mathrm{nmol}^{13}$ respectively.

\section{Optimal preload depending on TUI}

As the normal lymph node tissue and tumor are merged into one compartment, the TUI of antibody is valid for both tissues. The uptake of antibody into different lymphomas can vary considerably. ${ }^{11}$ For normal tissue (muscle, skin, etc.), an average uptake of $0.22 \mathrm{~mL} / 100 \mathrm{~g} / \mathrm{hour}$ was reported. ${ }^{19}$ As it is known that the permeability of tumor is higher and that lymphomas do not have elevated interstitial pressure (at least not as high as in other solid tumors ${ }^{20}$ ), values smaller than $0.22 \mathrm{~mL} / 100 \mathrm{~g} /$ hour were not considered. The upper limit TUI $=40 \mathrm{~mL} / 100 \mathrm{~g} /$ hour was chosen to test the influence of higher permeability. $\mathrm{Ag}_{\text {tu }}$ and $\mathrm{Ag}_{\mathrm{ra}}$ were set to $36 \mathrm{nmol}^{2}$ and $12 \mathrm{nmol}$, respectively.

\section{Optimal preload depending on spleen size}

The spleen can be considerably enlarged in patients with NHL. ${ }^{2}$ It has also been observed that the spleen size is an important determinant for the biodistribution. ${ }^{7}$ The normal spleen contains a mass of B cells of $\sim 38 \mathrm{~g}$. Therefore, the mass of B cells in the spleen was varied from $24 \mathrm{~g}(6 \mathrm{nmol} \mathrm{CD20})$ to $240 \mathrm{~g}$ (60 nmol CD20). The TUI and $\mathrm{Ag}_{\text {tu }}$ were set constant to the base values of $4 \mathrm{~mL} / 100 \mathrm{~g} /$ hour and $36 \mathrm{nmol}$, respectively.

\section{Results}

The optimal preload has been determined for different scenarios. The results are shown in Figures 2-4 and are described below.

\section{Optimal preload depending on tumor burden}

The simulations yielded that a preload of about $125 \mathrm{mg}$ led to the most favorable biodistribution for $\mathrm{Ag}_{\mathrm{tu}}=3.6-$
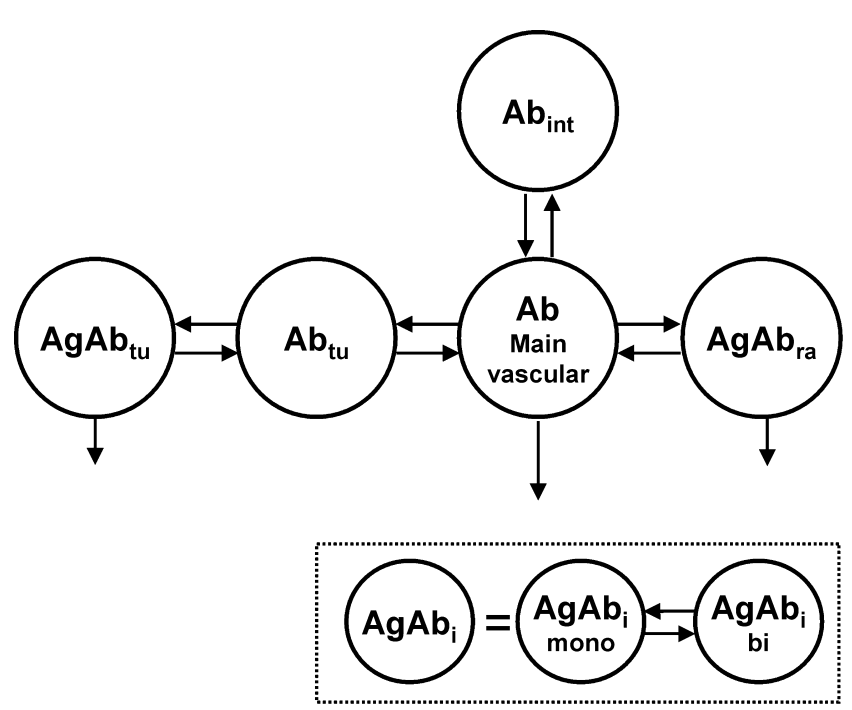

FIG. 1. Compartmental model. The model consists of two equivalent systems (one for the labeled and one for the unlabeled antibody), which are connected by the same number of antigens and the physical decay $\lambda_{\text {phys }}$. The antibody is administered into the main plasma compartment. There is a certain capacity of readily accessible antigens $\left(\mathrm{Ag}_{\mathrm{ra}}\right)$, where the antibody can directly bind from the serum because of discontinuous capillary structures. To bind to most of the antigens in the tumor $\left(\mathrm{Ag}_{\mathrm{tu}}\right)$, first the antibody has to pass the capillary walls. Degradation takes place wherever the antibody is bound. Degradation of unbound antibody is simplified by a linear degradation rate from the plasma compartment. $\mathrm{AgAb}_{\mathrm{i}}$, bound antibody ( $\mathrm{i}=\mathrm{tu}$ or $\left.\mathrm{ra}\right), \mathrm{Ab}$, free antibody; tu, tumor; ra, readily accessible; int, interstitial spaces; mono, monovalently bound; bi, bivalently bound. 


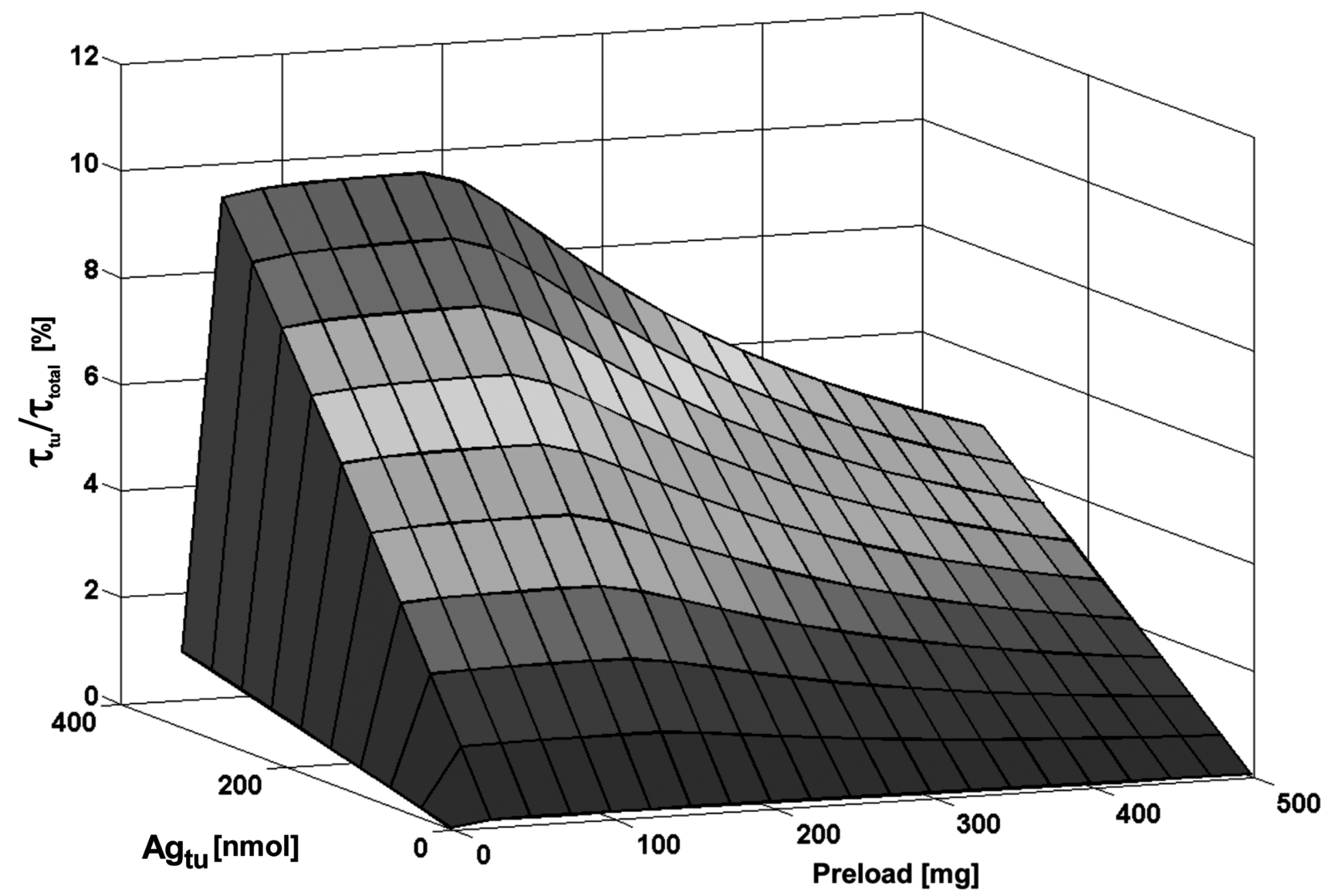

FIG. 2. Relative residence time of tumor $\left(\tau_{\mathrm{tu}} / \tau_{\text {total }}\right)$ depending on the administered antibody preload and on the amount of tumor antigens $\left(\mathrm{Ag}_{\mathrm{tu}}\right)$.

220 nmol. For higher numbers of antigens (256-328 nmol), $150 \mathrm{mg}$ resulted in an optimal biodistribution (Fig. 2). Such a reduced preload increased $\tau_{\text {tu }} / \tau_{\text {total }}$ by a factor of 1.0 $\left(\mathrm{Ag}_{\mathrm{tu}}=3.6 \mathrm{nmol}\right)$ or $2.1\left(\mathrm{Ag}_{\mathrm{tu}}=328 \mathrm{nmol}\right)$, compared with the standard preload of about $500 \mathrm{mg}$.

\section{Optimal preload depending on TUI}

The TUI strongly influenced the value of the optimal preload (Fig. 3). Increasing TUI yielded lower optimal preloads and higher $\tau_{\text {tu }} / \tau_{\text {total }}$ (for $0.22 \mathrm{~mL} / 100 \mathrm{~g} /$ hour 1 -fold to $40 \mathrm{~mL} / 100 \mathrm{~g} /$ hour 16-fold compared with the biodistribution applying $500 \mathrm{mg}$ ). Lower TUIs required a higher concentration of antibodies for adequate tumor uptake. However, for a very low TUI $(0.22 \mathrm{~mL} / 100 \mathrm{~g} / \mathrm{hour})$, a preload higher than $150 \mathrm{mg}$ did not improve the biodistribution.

\section{Optimal preload depending on spleen size}

With an increasing B-cell mass of the spleen, more antibodies are required to saturate the antigen sink of readily accessible antigens (Fig. 4). The optimal preload (25-125 mg) improved the ratio $\tau_{\text {tu }} / \tau_{\text {total }}$ by a factor of 2.4 compared with the standard preload of $500 \mathrm{mg}$.

\section{Discussion}

In this simulation study, a PBPK model was constructed to investigate the biodistribution of labeled anti-CD20 antibody depending on interpatient variability and preload. To identify the optimal preload, simulations with different tumor burdens, TUIs, and spleen sizes were conducted. The results suggest that when using the optimal preload a substantial improvement of tumor uptake is achievable.

In addition, the results of the present study show that there is an optimal cold dose for each patient, which is in agreement with recent findings. ${ }^{7}$ Moreover, an important result in the present study is that in no case the frequently administered amount of $250 \mathrm{mg} / \mathrm{m}^{2}$ leads to the most favorable biodistribution. This is especially true for tumors with higher TUI values: A fivefold increase of the TUI would lead to 8.5 times improved biodistribution when choosing the optimal amount. High accessibility for some lymphoma may be expected, as Knox et al. ${ }^{2}$ observed that for some patients even $0 \mathrm{mg}$ of unlabeled antibody was sufficient to image a number of known sites of disease. For a small TUI (here $0.22 \mathrm{~mL} / 100 \mathrm{~g} /$ hour), a high concentration of antibody in the serum is needed to transport the antibody over the capillary wall. However, a preload of $>150 \mathrm{mg}$ does not improve the biodistribution. To overcome the antigen sink even in case of $500 \mathrm{~g}$ readily accessible B cells, not $>19 \mathrm{mg}$ of unlabeled antibody is required. For a TUI of $4 \mathrm{~mL} / 100 \mathrm{~g} /$ hour, ${ }^{14}$ the simulations yielded an optimal dose of $125 \mathrm{mg}$, which is comparable to $2.5 \mathrm{mg} / \mathrm{kg}$, a dose where most of the known sites of disease (in 4 patients) were imaged in the study by Knox et al. ${ }^{2}$ The present work shows that for 


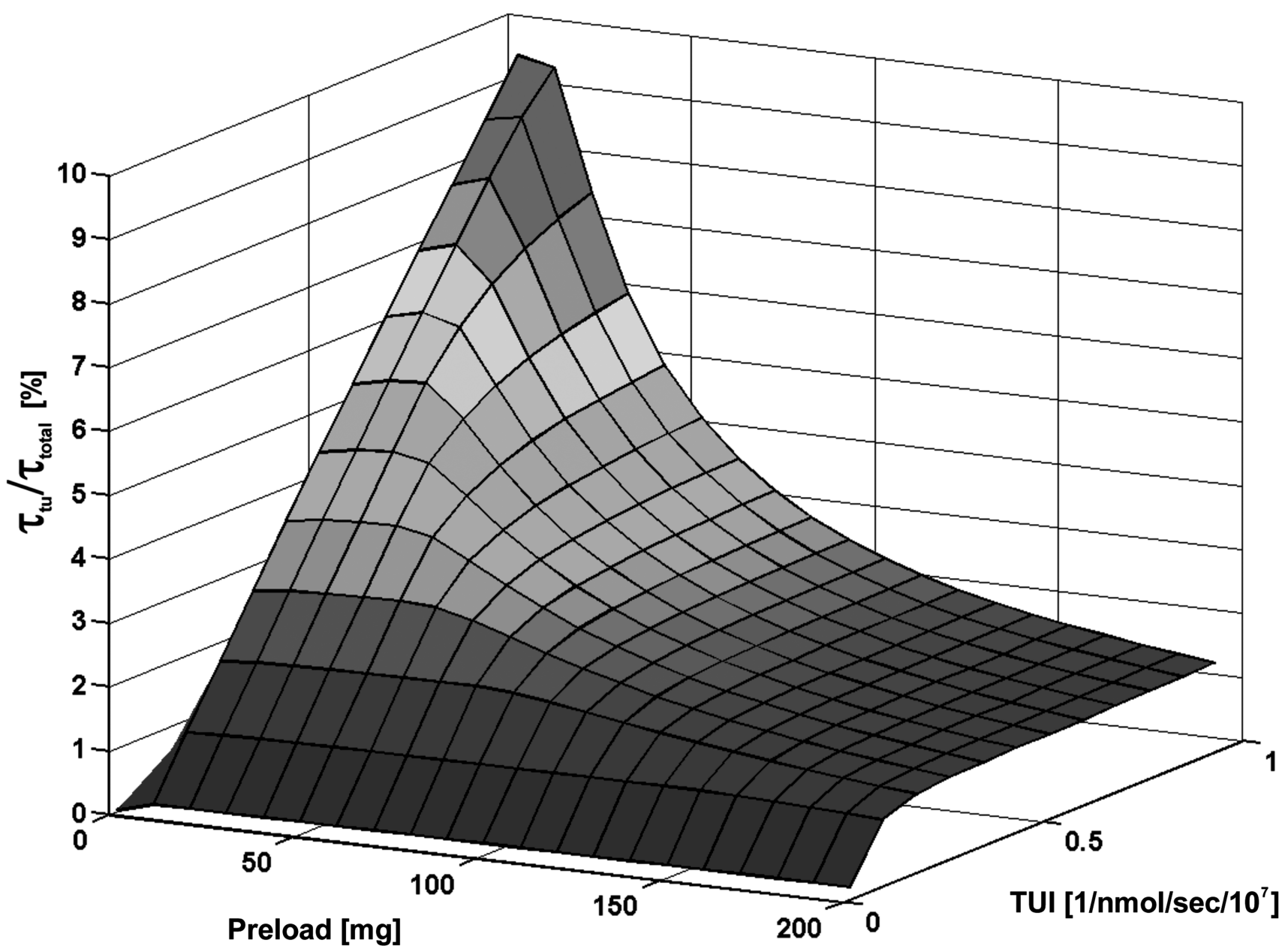

FIG. 3. Relative residence time of tumor $\left(\tau_{\mathrm{tu}} / \tau_{\text {total }}\right)$ depending on the administered antibody preload and on the tumor uptake index (TUI).

pretherapeutic measurement purposes the cold dose most probably can be reduced to $150 \mathrm{mg}$ or less.

Comparing these results with the modeling of RIT using anti-CD45 antibody, ${ }^{5}$ it can be observed that, in general, more antibody is necessary to saturate the anti-CD45 antigen sites in liver and spleen, as all leucocytes express CD45. However, modeling RIT with anti-CD20 antibody is a greater challenge, as the lymphomas vary strongly in their permeability $^{11}$ (accessibility of antigens) in contrast to the readily accessible target cells in the red marrow. ${ }^{10}$ Note that the red marrow is the target organ for myeloablative RIT with anti-CD45 or anti-CD66 antibody, whereas it is the critical organ for (nonmyeloablative) RIT using anti-CD20 antibody.

Certain assumptions were made to ensure a parsimonious model. The FcRn binding is not saturated until a total immunoglobulin $\mathrm{G}$ concentration of $7 \mathrm{mg} / \mathrm{mL}$ (which would correspond to $21 \mathrm{~g}$ antibody in this case $\mathrm{e}^{21}$ ). Therefore, the Fcspecific uptake rate was linearized. The TUI is a semiquantitative value ${ }^{14}$ that includes all mechanisms of transport through the capillary wall. Larger lymph nodes (tumor) might be differently permeable. In addition, even in the same patient different tumors may have different TUIs. Although the main model elements and parameters are derived from published models, which were fitted to real data, the presented model needs to be further validated with experimental data. This study was primarily concerned in the overall dependence on the preload and thus the effect of different degradation rates between labeled and unlabeled antibody was not investigated. Nevertheless, different degradation rates of labeled and unlabeled antibody and other features can be simply integrated into the model.

The optimal preload was defined as the amount of antibody leading to the maximal ratio of $\tau_{\text {tu }}$ and $\tau_{\text {total }}$ because this study was basically concerned in how much of the administered labeled antibody actually decays in the target organ. The ratio of $\tau_{\text {tu }}$ to $\tau$ of a well-perfused or antigen-rich (critical) organ such as the red marrow could also be used as a maximization criterion. Clearly, other criteria for optimal preload might lead to a different optimal amount of antibody.

As the results show a strong dependence of the optimal preload on the individual parameters, especially the TUI, this study suggests conducting pretherapeutic biodistribution measurements for each patient to identify the individual optimal dose for therapy. The presented model (or a similar one) could then be used to identify the individual model parameters for the patient. With these model parameters, 


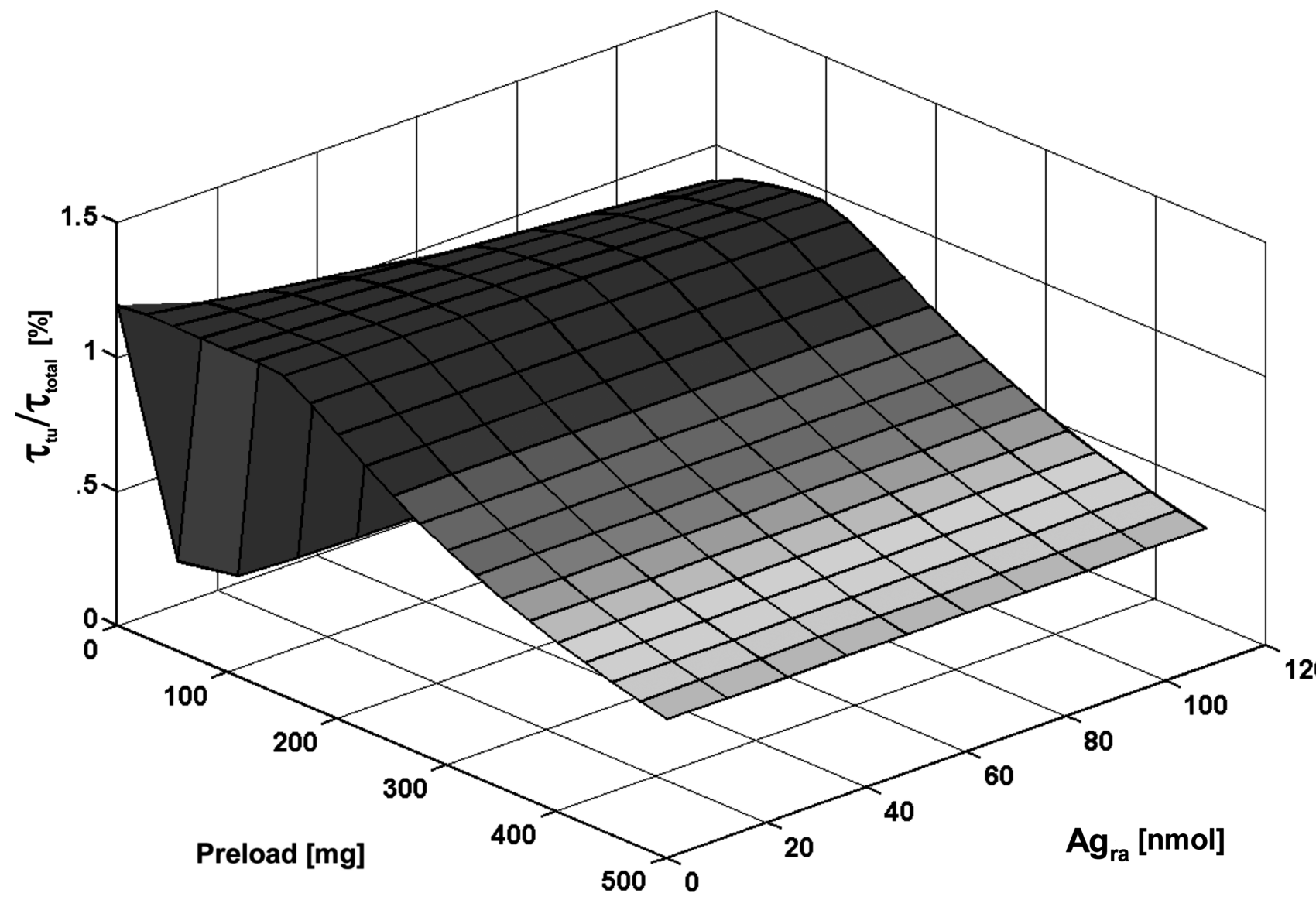

FIG. 4. Relative residence time of tumor $\left(\tau_{\mathrm{tu}} / \tau_{\text {total }}\right)$ depending on the administered antibody preload and on the amount of readily accessible antigens $\left(\mathrm{Ag}_{\mathrm{ra}}\right)$.

simulations using the model can be performed to identify the optimal preload. ${ }^{5}$ Higher amounts of antibody could be administered after RIT as consolidation. ${ }^{6}$

\section{Conclusions}

This study indicates that the uptake of radiolabeled antibody in RIT with anti-CD20 antibody might be considerably improved using the individually determined optimal amount of unlabeled antibody. In general, a reduction of antibody is advocated. An individual assessment of the optimal dose for therapy can probably be conducted using a pharmacokinetic model.

\section{Acknowledgments}

The authors gratefully acknowledge the grant from the Deutsche Forschungsgemeinschaft (German Research Foundation; grant no. GL 236/7-2).

\section{Disclosure Statement}

No competing financial interests exist.

\section{References}

1. Cheson BD, Leonard JP. Monoclonal antibody therapy for B-cell non-Hodgkin's lymphoma. N Engl J Med 2008; 359:613.
2. Knox S, Goris M, Trisler K, et al. Yttrium-90-labeled antiCD20 monoclonal antibody therapy of recurrent B-cell lymphoma. Clin Cancer Res 1996;2:457.

3. Glatting G, Müller M, Koop B, et al. Anti-CD45 monoclonal antibody YAML568: A promising radioimmunoconjugate for targeted therapy of acute leukemia. J Nucl Med 2006;47: 1335.

4. Sgouros G. Update: Molecular radiotherapy: Survey and current status. Cancer Biother Radiopharm 2008;23: 531.

5. Kletting P, Bunjes D, Reske SN, et al. Improving anti-CD45 antibody radioimmunotherapy using a physiologically based pharmacokinetic model. J Nucl Med 2009;50:296.

6. Sharkey RM, Press OW, Goldenberg DM. A re-examination of radioimmunotherapy in the treatment of non-Hodgkin lymphoma: Prospects for dual-targeted antibody/radioantibody therapy. Blood 2009;113:3891.

7. Gopal AK, Press OW, Wilbur SM, et al. Rituximab blocks binding of radiolabeled anti-CD20 antibodies (Ab) but not radiolabeled anti-CD45 Ab. Blood 2008;112:830.

8. Sharkey RM, Karacay H, Johnson CR, et al. Pretargeted versus directly targeted radioimmunotherapy combined with anti-CD20 antibody consolidation therapy of nonHodgkin lymphoma. J Nucl Med 2009;50:444.

9. Kletting P, Kull T, Bunjes D, et al. Radioimmunotherapy with anti-CD66 antibody: Improving the biodistribution using a physiologically based pharmacokinetic model. J Nucl Med 2010;51:484. 
10. Eger RR, Covell DG, Carrasquillo JA, et al. Kinetic model for the biodistribution of an ${ }^{111} \mathrm{In}$-labeled monoclonal antibody in humans. Cancer Res 1987;47:3328.

11. Schmid J, Möller P, Moldenhauer G, et al. Monoclonal antibody uptake in B-cell lymphomas: Experimental studies in nude mouse xenografts. Cancer Immunol Immunother 1993;36:274.

12. Dhingra S, Freedenberg M, Quo CF, et al. Computational modeling of a metabolic pathway in ceramide de novo synthesis. Proceedings of the 29th Annual International Conference of the IEEE EMBS Cité Internationale, Lyon, France, August 23-26, 2007;1405.

13. Westermann J, Pabst R. Distribution of lymphocyte subsets and natural killer cells in the human body. Clin Investig 1992;70:539.

14. Jain RK. Transport of molecules across tumor vasculature. Cancer Metastasis Rev 1987;6:559.

15. Matthews DC. Development of a marrow transplant regimen for acute leukemia using targeted hematopoietic irradiation delivered by ${ }^{131}$ I-labeled anti-CD45 antibody, combined with cyclophosphamide and total body irradiation. Blood 1995;85:1122.
16. Matthews DC, Badger CC, Fisher DR, et al. Selective radiation of hematolymphoid tissue delivered by anti-CD45 antibody. Cancer Res 1992;52:1228.

17. Ng CM, Bruno R, Combs D, et al. Population pharmacokinetics of rituximab (anti-CD20 monoclonal antibody) in rheumatoid arthritis patients during a phase II clinical trial. J Clin Pharmacol 2005;45:792.

18. Bikoue A, George F, Poncelet P, et al. Quantitative analysis of leukocyte membrane antigen expression: Normal adult values. Cytometry 1996;26:137.

19. Thomas GD, Chappell MJ, Dykes PW, et al. Effect of dose, molecular size, affinity, and protein binding on tumor uptake of antibody or ligand: A biomathematical model. Cancer Res 1989;49:3290.

20. Curti BD, Urba WJ, Alvord WG, et al. Interstitial pressure of subcutaneous nodules in melanoma and lymphoma patients: Changes during treatment. Cancer Res 1993;53: 2204.

21. Ferl GZ, Wu AM, DiStefano JJ 3rd. A predictive model of therapeutic monoclonal antibody dynamics and regulation by the neonatal Fc receptor (FcRn). Ann Biomed Eng 2005; 33:1640. 


\section{Appendix 1. Equations and Parameters}

\section{MODEL EQUATIONS (SEE MANUSCRIPT, FIG. 1)}

The following equations describe the transport of labeled (indexed with *) and unlabeled antibody to the antigen sites, its mono- and bivalent binding, ${ }^{1-3}$ degradation, and radioactive decay. The injection of antibody is simulated as a bolus using the bolus function of SAAM2. The variables are defined in Table 1. The compartment "readily accessible" (denoted with index "ra") is composed of all antigen sites in the liver, spleen, blood, and red marrow, which are readily accessible. The compartment "tumor" (denoted with " $t u$ ") is composed of all antigen sites of normal lymph node tissue and tumor.

\section{Constraint for Antigen Sites ( $\mathbf{i}=$ Readily} Accessible or Tumor)

$$
\begin{aligned}
\mathrm{Ag}_{\mathrm{i}}= & \mathrm{Ag}_{0, \mathrm{i}}-\mathrm{AgAb}_{\text {mono, } \mathrm{i}}-\mathrm{AgAb}_{\text {mono, } \mathrm{i}}^{*} \\
& -2 \cdot \mathrm{AgAb}_{\mathrm{bi}, \mathrm{i}}-2 \cdot \mathrm{AgAb}_{\mathrm{bi}, \mathrm{i}}^{*}
\end{aligned}
$$

\section{Bound Antibody ( $\mathbf{i}=$ Readily Accessible or Tumor)}

$$
k_{\text {on, bi }} \cdot\left[\mathrm{Ag}_{\mathrm{i}}\right]_{\mathrm{s}}=\frac{k_{\text {on, mono }} \cdot E \cdot \mathrm{Ag}_{\mathrm{i}}}{\mathrm{Ag}_{0, \mathrm{i}}} \cdot\left[\mathrm{Ag}_{0}\right]_{\mathrm{s}}
$$

$\left[\mathrm{Ag}_{\mathrm{i}}\right]_{\mathrm{s}}$ represents the surface concentration of unbound antigens on B cells.

The ratio of $k_{\text {on,mono }}$ to $k_{\text {on,bi }}\left(=E=1.67 \times 10^{6} \mathrm{~cm}^{-1}\right)$ used in the literature ${ }^{1}$ basically stems from the conversion of bulk to surface concentrations using average binding site concentrations.

\section{Differential Equations}

Monovalently bound antibody in tumor

$$
\begin{aligned}
& \frac{d}{d t}\left[\mathrm{AgAb}_{\text {mono, tu }}\right] \cdot V_{\mathrm{tu}}=2 \cdot k_{\text {on, mono }} \cdot \mathrm{Ag}_{\mathrm{tu}} \cdot \frac{\mathrm{Ab}_{\mathrm{tu}}}{V_{\mathrm{tu}}} \\
& -k_{\mathrm{on}, \mathrm{bi}} \cdot\left[\mathrm{Ag}_{\mathrm{tu}}\right]_{\mathrm{s}} \cdot \mathrm{AgAb}_{\text {mono, tu }} \\
& -k_{\text {off }} \cdot \operatorname{AgAb}_{\text {mono, tu }}+2 \cdot k_{\text {off }} \cdot \operatorname{AgAb}_{\text {bi, tu }} \\
& -\lambda_{\mathrm{db}} \cdot \mathrm{AgAb}_{\text {mono, tu }}+\lambda_{\text {phy }} \cdot \mathrm{AgAb}_{\text {mono, tu }}^{*} \\
& \frac{d}{d t}\left[\mathrm{AgAb}_{\text {mono, tu }}^{*}\right] \cdot V_{\mathrm{tu}}=2 \cdot k_{\text {on, mono }} \cdot \mathrm{Ag}_{\mathrm{tu}} \cdot \frac{\mathrm{Ab}_{\mathrm{tu}}^{*}}{V_{\mathrm{tu}}} \\
& -k_{\mathrm{on}, \mathrm{bi}} \cdot\left[\mathrm{Ag}_{\mathrm{tu}}\right]_{\mathrm{s}} \cdot \mathrm{AgAb}_{\text {mono, tu }}^{*} \\
& -k_{\text {off }} \cdot \operatorname{AgAb} b_{\text {mono, tu }}^{*}+2 \cdot k_{\text {off }} \cdot \operatorname{AgAb} b_{\text {bi, tu }}^{*} \\
& -\lambda_{\mathrm{db}} \cdot \mathrm{AgAb}_{\text {mono, tu }}^{*}-\lambda_{\text {phy }} \cdot \mathrm{AgAb}_{\text {mono, tu }}^{*}
\end{aligned}
$$

Monovalently bound antibody in readily accessible antigen compartment

$$
\begin{aligned}
& \frac{d}{d t}\left[\mathrm{AgAb}_{\text {mono, ra }}\right] \cdot V_{\mathrm{P}}=2 \cdot k_{\text {on, mono }} \cdot \mathrm{Ag}_{\text {ra }} \cdot \frac{\mathrm{Ab}_{\mathrm{P}}}{V_{\mathrm{P}}} \\
& -k_{\text {on, bi }} \cdot\left[\mathrm{Ag}_{\mathrm{ra}}\right]_{\mathrm{s}} \cdot \mathrm{AgAb} \mathrm{anono}_{\text {ra }} \\
& -k_{\text {off }} \cdot \operatorname{AgAb} b_{\text {mono, ra }}+2 \cdot k_{\text {off }} \cdot \operatorname{AgAb}_{\mathrm{bi} \text {, ra }} \\
& -\lambda_{\mathrm{db}} \cdot \mathrm{AgAb}_{\text {mono, ra }}+\lambda_{\text {phy }} \cdot \mathrm{AgAb}_{\text {mono, ra }}^{*} \\
& \frac{d}{d t}\left[\mathrm{AgAb}_{\text {mono, ra }}^{*}\right] \cdot V_{\mathrm{P}}=2 \cdot k_{\text {on, mono }} \cdot \mathrm{Ag}_{\mathrm{ra}} \cdot \frac{\mathrm{Ab}_{\mathrm{r}}^{*}}{V_{\mathrm{P}}} \\
& -k_{\text {on, bi }} \cdot\left[\mathrm{Ag}_{\mathrm{ra}}\right]_{\mathrm{s}} \cdot \mathrm{AgAb}_{\text {mono, ra }}^{*} \\
& -k_{\text {off }} \cdot \mathrm{AgAb}_{\text {mono, ra }}^{*}+2 \cdot k_{\text {off }} \cdot \mathrm{AgAb}_{\mathrm{bi} \text { ra }}^{*} \\
& -\lambda_{\mathrm{db}} \cdot \mathrm{AgAb}_{\text {mono, ra }}^{*}-\lambda_{\text {phy }} \cdot \mathrm{AgAb}_{\text {mono, ra }}^{*}
\end{aligned}
$$

Bivalently bound antibody in tumor

$$
\begin{aligned}
\frac{d}{d t}\left[\mathrm{AgAb}_{\mathrm{bi}, \mathrm{tu}}\right] & \cdot V_{\mathrm{tu}}=k_{\mathrm{on}, \mathrm{bi}} \cdot\left[\mathrm{Ag}_{\mathrm{tu}}\right]_{\mathrm{s}} \cdot \mathrm{AgAb}_{\mathrm{mono}, \mathrm{tu}} \\
& -2 \cdot k_{\mathrm{off}} \cdot \mathrm{AgAb}_{\mathrm{bi}, \mathrm{tu}} \\
& -\lambda_{\mathrm{db}} \cdot \mathrm{AgAb}_{\mathrm{bi}, \mathrm{tu}}+\lambda_{\mathrm{phy}} \cdot \mathrm{AgAb}_{\mathrm{bi}, \mathrm{tu}}^{*} \\
\frac{d}{d t}\left[\mathrm{AgAb}_{\mathrm{bi}, \mathrm{tu}}^{*}\right] & \cdot V_{\mathrm{tu}}=k_{\mathrm{on}, \mathrm{bi}} \cdot\left[\mathrm{Ag}_{\mathrm{tu}}\right]_{\mathrm{s}} \cdot \mathrm{AgAb}_{\mathrm{mono}, \mathrm{tu}}^{*} \\
& -2 \cdot k_{\mathrm{off}} \cdot \mathrm{AgAb}_{\mathrm{bi}, \mathrm{tu}}^{*} \\
& -\lambda_{\mathrm{db}} \cdot \mathrm{AgAb}_{\mathrm{bi}, \mathrm{tu}}-\lambda_{\mathrm{phy}} \cdot \mathrm{AgAb}_{\mathrm{bi}, \mathrm{tu}}^{*}
\end{aligned}
$$

Bivalently bound antibody in readily accessible antigen compartment

$$
\begin{aligned}
\frac{d}{d t}\left[\mathrm{AgAb}_{\mathrm{bi}, \mathrm{ra}}\right] & \cdot V_{\mathrm{P}}=k_{\mathrm{on}, \mathrm{bi}} \cdot\left[\mathrm{Ag}_{\mathrm{ra}}\right]_{\mathrm{s}} \cdot \mathrm{AgAb}_{\text {mono, ra }} \\
& -2 \cdot k_{\mathrm{off}} \cdot \mathrm{AgAb}_{\mathrm{bi}, \mathrm{ra}} \\
& -\lambda_{\mathrm{db}} \cdot \mathrm{AgAb}_{\mathrm{bi}, \mathrm{ra}}+\lambda_{\text {phy }} \cdot \mathrm{AgAb}_{\mathrm{bi}, \mathrm{ra}}^{*} \\
\frac{d}{d t}\left[\mathrm{AgAb}_{\mathrm{bi}, \mathrm{ra}}^{*}\right] & \cdot V_{\mathrm{P}}=k_{\mathrm{on}, \mathrm{bi}} \cdot\left[\mathrm{Ag}_{\mathrm{ra}}\right]_{\mathrm{s}} \cdot \mathrm{AgAb}_{\mathrm{mono}, \mathrm{ra}}^{*} \\
& -2 \cdot k_{\mathrm{off}} \cdot \mathrm{AgAb}_{\mathrm{bi}, \mathrm{ra}}^{*} \\
& -\lambda_{\mathrm{db}} \cdot \mathrm{AgAb}_{\mathrm{bi}, \mathrm{ra}}^{*}-\lambda_{\text {phy }} \cdot \mathrm{AgAb}_{\mathrm{bi}, \mathrm{ra}}^{*}
\end{aligned}
$$

Free antibody in interstitial spaces of tissues without $B$ cells

$$
\begin{aligned}
& \frac{d}{d t} \mathrm{Ab}_{\text {int }}=k_{\text {in, } \mathrm{n}} \cdot \mathrm{A} \mathrm{b}_{\mathrm{P}}-k_{\text {out }, \mathrm{n}} \cdot A b_{\text {int }}+\lambda_{\text {phy }} \cdot \mathrm{Ab}_{\text {int }}^{*} \\
& \frac{d}{d t} \mathrm{Ab}_{\text {int }}^{*}=k_{\text {in, } \mathrm{n}} \cdot \mathrm{Ab}_{\mathrm{P}}^{*}-k_{\text {out }, \mathrm{n}} \cdot \mathrm{Ab}_{\text {int }}^{*}-\lambda_{\text {phy }} \cdot \mathrm{Ab}_{\text {int }}^{*}
\end{aligned}
$$


Free antibody tumor

$$
\begin{aligned}
& \frac{d}{d t}\left[\mathrm{Ab}_{\mathrm{tu}}\right] \cdot V_{\mathrm{tu}}=-2 \cdot k_{\mathrm{on}, \mathrm{mono}} \cdot \mathrm{Ag}_{\mathrm{tu}} \cdot \frac{\mathrm{Ab}_{\mathrm{tu}}}{V_{\mathrm{P}}}+k_{\mathrm{off}} \cdot \mathrm{AgAb}_{\text {mono, tu }} \\
& +k_{\text {in, tu }} \cdot \mathrm{Ab}_{\mathrm{P}}-k_{\text {out }, \mathrm{tu}} \cdot \mathrm{Ab}_{\mathrm{tu}}+\lambda_{\text {phy }} \cdot \mathrm{Ab}_{\mathrm{tu}}^{*} \\
& \frac{d}{d t}\left[\mathrm{Ab}_{\mathrm{tu}}^{*}\right] \cdot V_{\mathrm{tu}}=-2 \cdot k_{\mathrm{on}, \mathrm{mono}} \cdot \mathrm{Ag}_{\mathrm{tu}} \times \frac{\mathrm{Ab}_{\mathrm{tu}}^{*}}{V_{\mathrm{P}}}+k_{\text {off }} \cdot \mathrm{AgAb}_{\text {mono, tu }}^{*} \\
& +k_{\text {in, tu }} \cdot \mathrm{Ab}_{\mathrm{P}}^{*}-k_{\text {out }, \mathrm{tu}} \cdot \mathrm{Ab}_{\mathrm{tu}}^{*}-\lambda_{\text {phy }} \cdot \mathrm{Ab}_{\mathrm{tu}}^{*}
\end{aligned}
$$

Free main vascular compartment

$$
\begin{aligned}
& \frac{d}{d t}\left[\mathrm{Ab}_{\mathrm{P}}\right] \cdot V_{\mathrm{P}}=-2 \cdot k_{\mathrm{on}, \mathrm{mono}} \cdot \mathrm{Ag}_{\mathrm{P}} \cdot \frac{\mathrm{Ab}_{\mathrm{P}}}{V_{\mathrm{P}}} \\
& +k_{\text {off }} \cdot \mathrm{AgAb}_{\text {mono, ra }}-\lambda_{\mathrm{du}} \cdot \mathrm{Ab}_{\mathrm{P}} \\
& -\left(k_{\text {in, tu }}+k_{\text {in, } \mathrm{n}}\right) \cdot \mathrm{Ab}_{\mathrm{P}}+k_{\text {out }, \mathrm{n}} \cdot \mathrm{Ab}_{\mathrm{tu}} \\
& +k_{\text {out }, \mathrm{n}} \cdot \mathrm{Ab}_{\text {int }}+\lambda_{\text {phy }} \cdot \mathrm{Ab}_{\mathrm{P}}^{*} \\
& \frac{d}{d t}\left[\mathrm{Ab}_{\mathrm{P}}^{*}\right] \cdot V_{\mathrm{P}}=-2 \cdot k_{\mathrm{on}, \mathrm{mono}} \cdot \mathrm{Ag}_{\mathrm{P}} \cdot \frac{\mathrm{Ab}_{\mathrm{P}}^{*}}{V_{\mathrm{P}}} \\
& +k_{\text {off }} \cdot \operatorname{AgAb} \mathrm{Ab}_{\text {mono, ra }}^{*}-\lambda_{\mathrm{du}} \cdot \mathrm{Ab}_{\mathrm{P}}^{*} \\
& -\left(k_{\text {in, tu }}+k_{\text {in, } \mathrm{n}}\right) \cdot \mathrm{Ab}_{\mathrm{P}}^{*}+k_{\text {out }, \mathrm{n}} \cdot \mathrm{Ab}_{\mathrm{tu}}^{*} \\
& +k_{\text {out }, \mathrm{n}} \cdot \mathrm{Ab}_{\text {int }}^{*}-\lambda_{\text {phy }} \cdot \mathrm{Ab}_{\mathrm{P}}^{*}
\end{aligned}
$$

\section{Definition of Transport Rates: Tumor/ Vascular $^{4,5}$}

$$
\begin{aligned}
& k_{\mathrm{in}, \mathrm{tu}}=\mathrm{TUI} \cdot \text { Mass }_{\mathrm{tu}} \\
& k_{\mathrm{out}, \mathrm{tu}}=k_{\mathrm{in}, \mathrm{tu}} \cdot \frac{V_{\mathrm{P}}}{V_{\mathrm{tu}}}=k_{\mathrm{in}, \mathrm{tu}} \cdot \frac{V_{\mathrm{P}}}{\operatorname{Mass}_{\mathrm{tu}} \cdot 0.2}
\end{aligned}
$$

\section{References}

1. Kaufman EN, Jain RK. Effect of bivalent interaction upon apparent antibody affinity: Experimental confirmation of theory using fluorescence photobleaching and implications for antibody binding assays. Cancer Res 1992;52:4157.

2. Kletting P, Kull T, Bunjes D, et al. Radioimmunotherapy with anti-CD66 antibody: Improving the biodistribution using a physiologically based pharmacokinetic model. J Nucl Med 2010;51:484.

3. Kletting P, Bunjes D, Reske SN, et al. Improving anti-CD45 antibody radioimmunotherapy using a physiologically based pharmacokinetic model. J Nucl Med 2009;50:296.

4. Jain RK. Transport of molecules across tumor vasculature. Cancer Metastasis Rev 1987;6:559.

5. Baxter LT, Zhu H, Mackensen DG, et al. Physiologically based pharmacokinetic model for specific and nonspecific monoclonal antibodies and fragments in normal tissues and human tumor xenografts in nude mice. Cancer Res 1994;54:1517.

6. Johnstone RW, Andrew SM, Hogarth MP, et al. The effect of temperature on the binding kinetics and equilibrium constants of monoclonal antibodies to cell surface antigens. Mol Immunol 1990;27:327.

7. Knox S, Goris M, Trisler K, et al. Yttrium-90-labeled antiCD20 monoclonal antibody therapy of recurrent B-cell lymphoma. Clin Cancer Res 1996;2:457.

8. Baxter LT, Zhu H, Mackensen DG, et al. Biodistribution of monoclonal antibodies: Scale-up mouse to human using a physiologically based pharmacokinetic model. Cancer Res 1995;55:4611.

9. Bikoue A, George F, Poncelet P, et al. Quantitative analysis of leukocyte membrane antigen expression: Normal adult values. Cytometry 1996;26:137.

10. Eger RR, Covell DG, Carrasquillo JA, et al. Kinetic model for the biodistribution of an ${ }^{111}$ In-labeled monoclonal antibody in humans. Cancer Res 1987;47:3328. 
Appendix Table 1. Parameter Definition

\begin{tabular}{|c|c|c|c|c|}
\hline Variable & Value & Unit & Source (Ref. no.) & \\
\hline$k_{\text {on,mono }}$ & Association rate monovalent & 0.03 & $\mathrm{~L} \mathrm{nmol}{ }^{-1} \min ^{-1}$ & 3 \\
\hline$k_{\text {on,bi }}$ & Surface association rate bivalent & $k_{\mathrm{on}, \mathrm{bi}}=k_{\mathrm{on}, \mathrm{mono}} \times E$ & $\mathrm{~cm}^{2} \mathrm{nmol}^{-1} \mathrm{~min}^{-1}$ & 1 \\
\hline$k_{\text {off }}$ & Dissociation rate & 0.3 & $\min ^{-1}$ & 6 \\
\hline$E$ & Enhancement factor & $1.67 \times 10^{6}$ & $\mathrm{~cm}^{-1}$ & 1 \\
\hline Mass $_{\text {tu }}$ & Tumor mass & $15-1330 \mathrm{~g}$ & $\mathrm{~g}$ & 7 \\
\hline$V_{\mathrm{P}}$ & Total plasma volume & 3000 & $\mathrm{~mL}$ & 3 \\
\hline$V_{\mathrm{tu}}$ & Interstitial distribution volume & Mass $_{\mathrm{tu}} \times 0.2$ & $\mathrm{~mL}$ & 8 \\
\hline$[\mathrm{Ag}]_{\mathrm{s}}$ & Surface concentration of antigen & $7.9 \times 10^{-5}$ & $\mathrm{nmol} \mathrm{cm}{ }^{-2}$ & 9 \\
\hline $\mathrm{Ag}_{\mathrm{i}}$ & Free antigens (ra or tu) & & nmol & \\
\hline $\mathrm{Ag}_{0, \mathrm{i}}$ & Total antigens (ra or tu) & $0.25 \mathrm{nmol} / \mathrm{g} \times$ Mass $_{\mathrm{i}}$ & nmol & \\
\hline $\mathrm{AgAb}_{\text {mono,i }}$ & Monovalently bound antibody (ra or tu) & & nmol & \\
\hline $\mathrm{AgAb} b_{\mathrm{bi}, \mathrm{i}}$ & Bivalently bound antibody (ra or tu) & & nmol & \\
\hline $\mathrm{Ab}_{\mathrm{i}}$ & $\begin{array}{l}\text { Unbound antibody of interstitial } \\
\text { spaces in normal tissue or tumor or plasma }\end{array}$ & & nmol & \\
\hline$k_{\mathrm{in}, \mathrm{n}}$ & Transport rate: $V_{\mathrm{P}}$ to interstitial space & 0.0017 & $\min ^{-1}$ & 10 \\
\hline$k_{\text {out,n }}$ & Transport rate: interstitial space to $V_{\mathrm{P}}$ & 0.005 & $\min ^{-1}$ & 10 \\
\hline$k_{\text {in, tu }}$ & Transport rate: $V_{\mathrm{P}}$ to interstitial space tumor & TUI $\times$ Mass $_{\mathrm{tu}}$ & $\min ^{-1}$ & 10 \\
\hline$k_{\text {out,tu }}$ & Transport rate: interstitial space tumor to $V_{\mathrm{P}}$ & $k_{\mathrm{in}, \mathrm{tu}} \times V_{\mathrm{P}} / V_{\mathrm{tu}}$ & $\min ^{-1}$ & 10 \\
\hline TUI & Tumor uptake index & 4 & $\mathrm{~mL}(100 \mathrm{~g})^{-1} \mathrm{~h}^{-1}$ & 4 \\
\hline$\lambda_{\mathrm{db}}$ & Degradation of bound antibody & $7.2 \times 10^{-5}$ & $\min ^{-1}$ & 2 \\
\hline$\lambda_{\mathrm{du}}$ & Degradation of unbound antibody & $3.9 \times 10^{-4}$ & $\min ^{-1}$ & 10 \\
\hline$\lambda_{\text {phy }}$ & Physical decay ${ }^{111}$ In & $1.72 \times 10^{-4}$ & $\min ^{-1}$ & 3 \\
\hline
\end{tabular}

ra, readily accessible; tu, tumor. 
